\title{
Penguatan Spiritualitas untuk Menghadapi Fenomena Dehumanisasi Akibat Teknologi Maju dan Industrialisasi
}

\author{
Zainul Muhibbin $^{1}$ dan Choirul Mahfud ${ }^{2}$ \\ ${ }^{1.2}$ UPT PMK Sosial Humaniora, FBMT, Institut Teknologi Sepuluh Nopember \\ muhibbin@mku.its.ac.id dan choirulmahfud@gmail.com
}

\begin{abstract}
ABSTRAK
Teknologi sebagai karya manusia telah menghasilkan kemudahan, kenyamanan, efektivitas dan hasil optimal dalam berbagai pekerjaan, namun di samping menghasilkan hal-hal yang positif ternyata juga membawa dampak negatif. Teknologi dan industrialisasi telah menyingkirkan fungsi manusia sebagai salah satu faktor produksi yang dominan. Teknologi yang seharusnya menjadi alat bagi manusia untuk melepaskan diri dari perbudakan kerja, justru berubah menjadi suatu mekanisme yang menyingkirkan manusia sendiri, di sinilah fenomena dehumanisasi menjadi nyata. Dengan demikian permasalahan penting yang menjadi titik tolak kajian ini adalah bagaimana strategi menumbuhkan aspek-aspek human dignity kembali menguat di tengah arus perkembangan teknologi maju dan industrialisasi? Dari kajian yang telah dilakukan maka ditemukan hasil bahwa pada hakikatnya manusia disamping memiliki aspek ragawi juga memiliki potensi jiwa yang universal. Dalam jiwa ini manusia memiliki spiritualitas. Oleh karena itu, untuk menangkal fenomena dehumanisasi akibat teknologi maju dan industrialisasi adalah dengan penguatan kembali potensi spiritualitas manusia secara universal agar manusia dapat memanusiakan manusia, dan mengembalikan manusia kepada martabatnya yang luhur.
\end{abstract}

Kata kunci: martabat, spiritualitas, dehumanisasi, teknologi, industrialisasi.

\section{PENDAHULUAN}

Teknologi merupakan karya intelektual dan inovasi manusia yang dibuat sebagai alat yang dapat membantu aktivitas manusia dalam segala hal. Teknologi menghasilkan kemudahan, kenyamanan, efektivitas dan hasil optimal dalam berbagai pekerjaan. Di samping menghasilkan halhal yang positif dan bermanfaat ternyata teknologi juga membawa dampak negatif yang harus dicermati dan mendapat perhatian serius. Industrialisasi yang tidak lepas dari sentuhan teknologi juga demikian, di samping menghasilkan banyak manfaat untuk memenuhi kebutuhan manusia ternyata juga membawa dampak negatif bagi manusia dan kemanusiaan.

Permasalahan kesenjangan telah tampak, bahwa teknologi dan industrialisasi telah menyingkirkan fungsi manusia sebagai salah satu faktor produksi yang dominan. Pabrik-pabrik berskala besar lebih memilih memakai mesin dalam kegiatan produksinya dan merumahkan jutaan karyawan dengan alasan efisiensi. Teknologi yang seharusnya menjadi alat bagi manusia untuk melepaskan diri dari perbudakan kerja, justru berubah menjadi suatu mekanisme yang memperbudak dan menyingkirkan manusia sendiri, di sinilah fenomena dehumanisasi menjadi nyata.

Garis marka kesenjangan muncul ke permukaan dan tidak bisa dipungkiri lagi. Individuindividu pemegang teknologi dan penguasa industri tidak lagi memperdulikan manusia pekerja yang telah tersingkir. Suatu komunitas baru lahir bersifat eksklusif di tengah masyarakat luas yang mengalami kegelisahan. Pada tataran ini maka pemaknaan fungsi manusia sebgai makhluk sosial menjadi sempit, hanya dibatasi oleh komunitas saja. Hal ini membuat manusia menjadi enggan berhubungan dengan orang lain yang bukan komunitas mereka. Sikap ketidakacuhan terhadap 
lingkungan berkembang, dan menjadikan fungsi sosial manusia menjadi kurang optimal sehingga rentan terhadap konflik. Nilai-nilai humanitas menjadi persoalan yang harus diberi perhatian serius.

Oleh karena itu, nilai-nilai kemanusiaan universal harus dikembalikan sebagaimana mestinya. Pembicaraan tentang teknologi, industrialisasi dan globalisasi harus ditempatkan dalam kerangka humanisasi. Dengan demikian permasalahan penting yang menjadi titik tolak kajian ini adalah bagaimana strategi menumbuhkan aspek-aspek human dignity kembali menguat di tengah arus perkembangan teknologi maju dan industrialisasi?

Kajian ini bertujuan untuk meneliti aspek-aspek yang menjadi penyebab terjadinya dehumanisasi dan kemudian mencari jawaban untuk menemukan strategi yang tepat dalam upaya menetralisir dan mengembalikan martabat kemanusiaan sebagai solusi.

\section{MANUSIA DAN SPIRITUALITAS}

Rasionalisasi yang telah menjadi sikap hidup mengarah pada persoalan ketergantungan yang besar manusia terhadap teknologi. Pada akhirnya manusia meninggalkan spiritualitasnya karena hanya fokus pada pencapaian materi. Ketimpangan akan terjadi ketika capaian tersebut tidak seimbang dan merata. Hal ini akan menimbulkan dampak kurangnya kontrol sosial terhadap kehidupan individi dan masyarakat. Masyarakat sangat tergantung pada perkembangan teknologi, secara tidak sadar, kehidupan yang berjalan saat ini sangat tergantung kepada teknologi. Seakanakan ketiadaan teknologi bisa jadi membuat seseorang tidak merasa hidup.

Teknologi dan industrialisasi secara global mengakibatkan masyarakat terdehumanisasi dengan sikap dan pola pikir materialisme dan empirisme. Masuknya barang-barang teknologi yang sudah menjadi produk industri membuat masyarakat terlena oleh kenyamanan dan kenikmatan materialistis. Secara tidak terasa masyarakat teralienasi dan lupa akan jati dirinya sebagai bangsa religious. Individu-individu masyarakat mulai banyak yang meninggalkan spiritualitasnya padahal potensi spiritual itu merupakan jiwa yang dimiliki manusia sejak lahir. Penguatan spiritualitas bagi individu-individu masyarakat dapat memberikan makna besar dalam kehidupan, oleh karena itu upaya ke arah ini menjadi urgen (Murdiono, 2010). Eksistensi manusia adalah terdiri dari jiwa dan raga. Ketika manusia meninggalkan jiwanya (spiritualitas) maka berarti dia hidup di luar eksistensinya.

Istilah spiritualitas seringkali disalahartikan dan dilihat sebagai sesuatu yang konteksnya sama (identik) dengan agama, keyakinan tertentu, aturan moral dan tradisi-tradisi mitologi. Spiritualitas pada dasarnya bukanlah sesuatu yang formal, terstruktur dan terorganisir seperti agama dan sistem kepercayaan pada umumnya. Spiritualitas berasal dari kata 'spiritus' yang artinya adalah nafas kehidupan. Spirit merupakan kekuatan yang tidak terlihat yang memberikan nafas bagi kehidupan dan memiliki daya dorong dalam berbuat, menghidupkan dan memberikan energi. Spirit membantu manusia dalam mendefinisikan kebenaran, keunikan diri dan menegaskan individualitas seseorang. Sedangkan agama adalah sistem ajaran yang terdiri dari kepercayaan, ritual dan normanorma yang menjadi tuntunan hidup manusia. Agama pada umumnya merepresentasikan jalan spiritual seseorang. Agama merupakan suatu sistem yang mapan untuk suatu kekuatan yang tidak bersifat materi.

Sebagai makhluk Tuhan, manusia diciptakan dengan memiliki tubuh (raga), akal, emosi dan jiwa (spirit). Spiritualitas memberikan ekspresi bahwa ada sesuatu di dalam diri manusia; yang berkaitan dengan aspek non-fisik, dengan kekuatan yang datang dari dalam diri (jiwa). Spiritualitas menjadi suatu kesadaran yang menghubungkan manusia dengan Tuhan dan dapat merefleksikan nilai-nilai seperti memberikan kontribusi positif kepada umat manusia serta alam semesta. Ini merupakan pilar transendensi manusia (Rogib, 2011). Peran spiritualitas sangat penting bagi kehidupan, baik dalam konteks kehidupan berkeluarga, bermasyarakat bahkan pada aktivitas berkarya dan berprofesi. 
Pengalaman spiritual (bertuhan) adalah pengalaman yang unik karena bisa jadi irrasional, dan autentik bagi manusia karena manusia memiliki ruhaniah. Pengalaman bertuhan merupakan bagian yang sangat erat dalam diri manusia dan mempengaruhi kepribadian setiap orang. Manusia harus memperhatikan aspek spiritualitas karena hal ini merupakan unsur yang ada dalam dirinya, dan manusia memerlukan spiritualitas untuk mencapai tujuan hidup yang hakiki, mengingat manusia merupakan makhluk jasmani dan ruhani. Oleh karena itu manusia jangan sampai meninggalkan spiritualitasnya sebab hanya akan menjadikan manusia kehilangan jati dirinya.

\section{DEHUMANISASI DI ERA TEKNOLOGI DAN INDUSTRIALISASI}

Era modern yang ditandai dengan kemajuan ilmu pengetahuan, teknologi dan industrialisasi melahirkan gaya hidup baru yang sama sekali berbeda dengan kultur lama. Penggunaan teknologi media komunikasi elektronik berbasis internet, seperti e-mail, sms atau aplikasi media sosial lainnya dalam berkomunikasi dengan orang lain ternyata dapat merubah gaya seseorang dalam bertutur kata dan berbahasa. Nilai-nilai sopan santun dalam berkomunikasi akhirnya pudar dan tidak lagi banyak digunakan. Permainan game online dan penggunaan fasilitas transaksi online lainnya membuat orang menjadi malas keluar rumah, sibuk dengan dirinya dan seolah-olah tidak lagi memerlukan bertemu dengan orang lain. Hal ini akan berdampak pada pola sosialisasi mereka dengan lingkungannya dan interaksi dengan sesama. Pada akhirnya pola ini melahirkan sikap hidup individualistis dan konsumtif.

Pada hakikatnya teknologi adalah alat sebagai hasil dari aplikasi ilmu pengetahuan. Teknologi adalah karya manusia yang dikembangkan melalui inovasi-inovasi kreatif hingga menghasilkan manfaat yang lebih banyak, mempermudah segala aktivitas dan mampu meningkatkan kesejahteraan manusia untuk mencapai kehidupan yang lebih baik. Namun, peningkatan kapaisitas yang dihasilkan teknologi ternyata juga membawa dampak negatif yang menyertainya. Teknologi yang diharapkan mampu menggantikan manusia dari pola perbudakan kerja, justru berubah menjadi suatu mekanisme yang menyingkirkan manusia sendiri dari berbagai bidang pekerjaan. Pekerjaan dalam proses industri yang semula dipegang manusia telah digantikan oleh mesin-mesin berbasis teknologi. Penguasa-penguasa industri mulai berfikir mekanis dan menganggap manusia pekerja sebagai "robot-robot" mekanik dan mengesampingkan sisi humanitas. Pada gilirannya sikap ini melahirkan pola orientasi pada barang produksi semata dan orientasi materialistis.

Realitas mutakhir era industrialisasi dewasa ini telah memasuki tahap perkembangan yang disebut revolusi industri 4.0 yang ditandai oleh langkah digitalisasi. Pada tahap ini industrialisasi bukan hanya mengganti energi hidup dengan mesin-mesin akan tetapi pikiran manusia pun diganti oleh alat-alat kecerdasan buatan. Dengan kecerdasannya, manusia menciptakan mesin kecerdasan buatan untuk menggantikan pikirannya sendiri. Ketika mesin-mesin sudah menguasai pikiran manusia, secara tidak sadar manusia saat ini telah berhenti menjadi "manusia", beralih menjadi robot-robot yang tidak lagi bias berpikir manusiawi, tidak berperasaan, dan pada akhirnya menumbuhkan sikap egoistis dan tidak memiliki kepedulian.

Dehumanisasi bisa dikatakan sebagai menonmanusiakan manusia. Fenomena ini muncul di era industrialisasi yang telah menggantikan peran manusia dengan mesin, robot dan sistem digitalisasi. Di satu sisi manusia tidak lagi diperlakukan sebagai manusia dan di sisi lain manusia sudah menjadi demikian tergantung kepada teknologi. Tanpa teknologi alat transportasi manusia merasa tidak bisa bepergian, tanpa teknologi mesin produksi manusia merasa tidak mampu berkarya, tanpa teknologi alat komunikasi manusia merasa tidak bisa berinteraksi, dan seterusnya. Ketergantungan ini membuat manusia menjadi kehilangan jati dirinya sebagai makhluk kreatif dan mandiri, dan karena ketergantungan ini pula manusia kehilangan jati dirinya sebagai makhluk sosial. Demikian juga karena kenyamanannya menikmati teknologi manusia melupakan aspek spiritualitas yang dimilikinya sejak lahir (Sauqi, 2010). Di sinilah akhirnya manusia kahilangan kemanusiaannya. 
Dalam beberapa literature hasil penelitian para ahli, proses dehumanisasi ini sangat linier dengan terjadinya alienasi (keterasingan jiwa) yang dialami manusia. Kapitalisasi menyebabkan lahirnya manusia-manusai robot. Sekularisasi mengakibatkan munculnya ketercerabutan spiritual. Ateisme dan pola agnostik menyebabkan manusia kehilangan potensi rohaninya. Berdasarkan kenyataan-kenyataan tersebut maka langkah yang harus segera diambil, bahkan sangat urgen, adalah mengembalikan manusia kepada jati diri aslinya, yaitu manusia sebagai insan yang memiliki unsur raga dan jiwa sekaligus. Manusia tidak boleh dipamahi hanya eksis berupa raga semata karena pada hakikatnya manusia memiliki unsur jiwa yang ada sejak diciptakan dan lahir di dunia.

\section{PENGUATAN SPIRITUALITAS}

Manusia, tidak bisa dipungkiri, adalah makhluk yang disebut insan, mempunyai potensi jiwa (spiritual) di samping unsur raga (fisik). Oleh karena itu manusia pada hakikatnya tidak bisa dipisahkan dari spiritualitasnya, karena dua unsur spiritual dan fisik yang dimiliki manusia itu merupakan dua hal yang menyatu dalam satu eksistensi. Dengan demikian manusia menjadi butuh akan agama dan ajaran ketuhanan untuk menjadi pegangan mental yang sangat diperlukan sebagai penguatan jiwa. Fakta itu memang telah menjadi fitrah (unsur bawaan) bagi manusia.

Spiritualitas dan agama memang merupakan suatu konteks yang berbeda namun selalu terkait tidak terpisahkan. Spiritualitas lebih dilihat sebagai potensi batini dalam jiwa menuju kesadaran akan nilai-nilai universal seseorang. Sedangkan agama merupakan muatan dari luar diri seseorang yang terdiri dari fondasi keyakinan yang menenangkan jiwa, aktivitas ritual yang menyejukkan batin, dan norma-norma etika sebagai penuntun tingkah laku luhur. Agama lebih dilihat sebagai sumber eksternal sedangkan spiritualitas sebagai sumber internal seseorang dalam memandang kehidupan. Dengan demikian, spiritualitas dapat dijangkau oleh semua orang baik yang beragama maupun yang tidak, akan tetapi spiritualitas dapat terkikis hilang bila tidak dibina dan dikembangkan dengan menggunakan agama (Roqib, 2011). Manusia dapat mengalami proses transformasi dalam berbagai aspek kehidupan, oleh karena itu manusia membutuhkan pedoman hidup universal yang dapat menyentuh aspek jiwa sekaligus raga, yaitu agama.

Spiritualitas memiliki dua kompetensi yaitu vertikal dan horizontal. Kompetensi vertikal spiritualitas adalah hasrat untuk melampaui ego. Kompetensi ini bisa berkaitan dengan Tuhan, jiwa, alam immateri, eksistensi metafisik lainnya. Kompetensi vertikal lebih kepada perwujudan sesuatu yang tidak dapat diindera. Sedangkan kompetensi horizontal dalam spiritualitas adalah hasrat untuk melayani dan berinteraksi dengan orang lain, bumi dan lingkungan yang lebih luas. Komponen horizontal ini ditunjukkan dengan bagaimana seseorang berusaha untuk memberikan kontribusi melalui tindakannya (Howard, 2002). Komponen ini lebih mengarah kepada perwujudan sesuatu yang dapat dilihat.

Melemahnya spiritualitas dapat mengakibatkan manusia kehilangan potensi rohaninya, hilangnya pelindung jiwa ketika manusia mengalami tekanan psikologis, tidak dimilikinya lagi norma universal-absolut yang menjadi pegangan hidup substansial, dan pada akhirnya manusia mengalami kegersangan spiritual, atau yang sering disebut alienasi jiwa.

Manusia harus memperhatikan aspek spiritualitasnya karena pada dasarnya manusia memerlukan spiritualitas untuk mencapai tujuan hidup yang hakiki. Agar manusia kembali memiliki jati dirinya dan menemukan kembali sentuhan manusiawi dalam kehidupannya, maka penguatan spiritualitas menjadi urgen dilakukan. Penguatan spiritualitas ini secara filosofis dapat dikatakan sebagai penguatan visi llahi, yaitu potensi bertuhan. Untuk mencapai visi llahi yang kokoh diperlukan proses aktualisasi akhlak Tuhan yang ada dalam diri setiap manusia. Untuk itu diperlukan pembinaan jiwa secara sistematis dan berkesinambungan dengan memadukan antara olah pikir, olah rasa, olah jiwa, dan olah raga. Sejalan dengan itu, Sayyed Hossein Nasr menawarkan terapi spiritual untuk mengatasi problematika manusia modern. la menghimbau manusia modern untuk mendalami dan menggunakan jalan tasawuf dalam konteks kemodernan, sebab hal inilah yang dapat memberikan 
jawaban-jawaban terhadap kebutuhan spiritual mereka (Nasr, 1994). Dalam konteks ini yang dapat diadopsi dari tasawuf adalah prinsip ajaran dan metodologinya.

Dalam perspektif Islam, tasawwuf sebagai metode penyucian jiwa, secara umum, memiliki prinsip-prinsip positif yang mampu mengembangkan spiritualitas manusia untuk kemudian mendorong lahirnya moralitas luhur. Prinsip-prinsip tersebut bersifat praktis dan aplikatif, yaitu muhasabah (introspeksi diri), taubah (kembali kepada Allah), dzikir (mengingat Allah) dan taqorrub (mendekatkan diri kepada Allah). Prinsip tasawwuf ini dapat menjadi sumber gerak, motivasi dan sumber nilai yang dapat menjadi landasan hidup (Rosyidi, MA, 2004). Dengan demikian seseorang bisa selalu berada di jalan yang lurus, yaitu jalan kebaikan. Melangkah dengan baik dan benar sesuai dengan yang dikehendaki Allah dalam setiap aktivitas kehidupannya.

Secara metodologis aplikasi prinsip ajaran tasawuf tersebut dapat dilakukan dengan tafakkur wa ta'ammul, yaitu olah pikir. Dengan kontemplasi dan introspeksi diri, seseorang akan kembali menyadari bahwa dirinya tidak lain adalah seorang makhluk ciptaan Tuhan yang posisi dan derajatnya setara dengan manusia lain. Oleh karena itu tidak sepantasnya seseorang merendahkan dan memperbudak orang lain, merugikan dan memperdaya orang lain, serta menjadikan orang lain sebagai robot-robot industri. Saatnya setiap orang kembali kepada Tuhan dan kembali kepada jati dirinya sebagai insan yang bermoralitas luhur.

Tadzawwuq, yaitu olah rasa. Dengan mengingat eksistensi Tuhan sebagai Yang Maha Kuasa disertai batin yang tunduk di bawah kekuasaan-Nya maka setiap orang akan merasakan kehadiran Tuhan dalam egonya. Di sini seseorang akan menemukan kelembutan, kasih sayang, empati dan persaudaraan sesama manusia. Maka dari itu tidak ada lagi kebohongan, tipu daya dan pengkhianatan yang merugikan orang lain, karena sesama manusia adalah saudara dalam kemanusiaan. Manusia harus kembali kepada hakikat dirinya sebagai makhluk yang bermartabat.

Riyādhah, yaitu olah jiwa. Dengan menjalin interaksi kepada Tuhan secara kontinyu dapat dihasilkan jiwa religius. Kedekatan batini seseorang kepada Tuhannya menghasilkan kontrol internal yang bersifat melekat dalam diri. Hal ini sangat penting untuk menumbuhkan sikap hidup seseorang menjadi lebih konsisten dalam berpegang kepada kebenaran dan menciptakan kebaikan. Setiap orang dalam posisi apapun akan menjadi lebih bijaksana dalam mengambil keputusan, berpikir analitik dalam mengambil tindakan, dan berpandangan jernih dalam bersikap. Pada akhirnya integritas dapat tumbuh dari sifat jiwa ini.

Rihlah wa jihād, yaitu olah raga. Kesehatan dan kesegaran jasmani sangat penting untuk mendukung kesehatan rohani. Etos kerja seseorang akan menjadi baik bila ada keterpaduan antara kesehatan jiwa dan kesehatan raga, kesejukan rohani dan kesegaran jasmani, serta kekuatan mental dan ketahanan fisik. Semangat juang yang tumbuh dari dorongan jiwa akan melahirkan aktivitas kerja yang bermakna. Selanjutnya produktivitas dengan karya-karya inovatif akan banyak dihasilkan dari jiwa dan raga yang sehat ini.

Spiritualitas membantu setiap individu menemukan makna dan tujuan dalam hidup mereka, di samping itu juga dapat mencerminkan nilai personalnya. Nilai personal ini merefleksikan hasrat untuk membuat baik dan menghasilkan kebaikan, serta menjadikan semua yang dihasilkan adalah manfaat bagi dunia dan kehidupan yang lebih luas (Sauq, 2010). Oleh karena itu, memiliki kekuatan spiritualitas sangat penting untuk membuat manusia menjadi individu-individu yang utuh, bermakna dan bermartabat.

\section{KESIMPULAN}

Dari uraian di atas, dapat ditarik kesimpulan bahwa kemajuan teknologi dan arus industrialisasi, disamping melahirkan kemanfaatan hasil yang positif ternyata juga membawa dampak negatif bagi manusia. Sisi negatif ini tidak boleh dibiarkan meluas dan merusak kehidupan umat manusia. Oleh karena itu harus ada tindakan antisipatif untuk menghadapi dan menetralisir dampak 
negatif tersebut. Dari hasil penelitian dan kajian yang telah dilakukan maka dapat ditemukan inti persoalannya dan kemudian dirumuskan solusinya, yiatu permasalahan spiritualitas manusia.

Spiritualitas mempunyai peran penting dalam membangun moralitas manusia. Spiritualitas dapat membuat manusia mampu mengelola egosentrisme, mengendalikan dorongan hawa nafsu, dan mengarahkan orientasi materi kepada produktivitas yang lebih bermanfaat. Dengan prinsip dan metode tasawuf seseorang dilatih untuk mengedepankan makna dan visi llahiyah dalam kehidupan. Spiritualitas sebagai pintu menuju Tuhan tidak akan menguat manakala jiwa selalu terkooptasi oleh keinginan ragawi yang bersifat kebendaan.

Setiap orang memiliki aspek spiritualitas dalam diri, namun tidak semua orang mampu mengaktualisasikan potensi tersebut menjadi kesadaran spiritual. Orang yang memiliki kesadaran spiritual akan memiliki beberapa kemampuan khusus, diantaranya mampu menemukan kekuasaan Yang Maha Kuasa, merasakan kelezatan ibadah, memahami nilai hakiki keabadian, menemukan makna hidup, membangun harmonisasi dan keselarasan dengan semesta, menghadirkan intuisi dan menemukan hakikat metafisik sebagai puncak kesadaran Ilahiyah, yang pada akhirnya mewujudkan kebaikan, manfaat dan kesejahteraan untuk sesama manusia, lingkungan dan kehidupan di alam ini.

\section{DAFTAR PUSTAKA}

Howard, S. (2002). A spiritual perspective on learning in the workplace. Journal of Managerial Psychology, 17(3), 230-242. https://doi.org/10.1108/02683940210423132

Murdiono, M. (2010). Strategi Internalisasi Nilai-Nilai Moral Religius dalam Proses Pembelajaran di Perguruan Tinggi Mukhamad Murdiono. Cakrawala Pendidikan, Edisi khus(Jurnal Ilmiah Pendidikan), 99-111. https://doi.org/http://dx.doi.org/10.21831/cp.v1i3.239

Nasr, S. H. (1994). Menjelajah dunia modern: bimbingan untuk kaum muda muslim (1st ed.). Bandung: Penerbit Mizan.

Roqib, M. (2011). Penguatan Spiritualitas Islam Melalui Budaya Profetik. Ibda'. Jurnal Kebudayaan Islam, 9(1), 1-13. Retrieved from http://ejournal.iainpurwokerto.ac.id/index.php/ibda/article/view/25

Rosyidi, MA, R. (2004). Dakwah Sufistik Kang Jalal (1st ed.). Jakarta: Paramadina.

Sauqi, A. (2010). Meraih Kedamaian Hidup Kisah Spiritualitas Orang Modern (1st ed.). Yogyakarta: Teras. 